\title{
The Influence of Parental Involvement on Academic Achievement in Boarding and Non-Boarding Schools
}

\author{
L.S. Maphoso \\ Department of Psychology of Education \\ University of Limpopo, Private Bag x 1106 Sovenga 0727, South Africa \\ maphosols@sabc.co.za \\ Dikeledi Mahlo \\ Department of Inclusive Education \\ University of South Africa, PO Box 392 Pretoria 0003, South Africa \\ mahlofd@unisa.ac.za
}

Doi:10.5901/mjss.2014.v5n2p155

\begin{abstract}
Why do parents send their children to boarding schools? Is it for their children's best education? If this is the reason, is it true that learners at boarding schools receive better education than those in non-boarding schools? This study investigates the differences in parental involvement between the two, the relationship between parental involvement and academic achievement and the difference in academic achievement between boarding and non-boarding schools of Grade 12 learners of the Capricorn District in the Limpopo Province of South Africa. A simple random sample was drawn from the population of three hundred and thirty-nine (339) schools and comprising 51 principals, 158 teachers and 290 learners from 51 schools in the Province. Ten of the 51 schools selected had boarding houses, whereas the remaining 41 had none. The School Environmental Questionnaire (SEQ) consisted of closed questions to determine if the school was boarding or non-boarding and the level of parental involvement. The Capricorn District Academic Summary Report of the Grade 12 results was used to determine academic achievement. The data analysis technique used was the $t$-test. The results revealed a significant difference between parental involvement in learners from boarding and non-boarding schools but that there was no significant difference in the parental involvement of children in low and high achieving schools. Results also indicated a significant difference in academic performance between boarding and non-boarding schools, with boarding schools performing better than non-boarding schools.
\end{abstract}

Keywords: boarding schools, non-boarding schools, parental involvement, academic achievement.

\section{Introduction}

Parents are at the forefront in ensuring that their children receive an education, however sending them to a particular school without ensuring it has a proper environment in which they can learn can undermine their good intentions. As a representative from the Department of Education in the Limpopo Province, Seima Cairos (South African Broadcasting Corporation, SABC, 2012) said, parents cannot surrender responsibility for their children's education, affirming the argument of Hoover-Dimpsy and Sandler (1995) that parental involvement influences children's development and educational outcomes through such mechanisms as modelling, reinforcement, and instruction. Parents who like reading, for instance, are likely to influence their children also to like reading. Everyday experiences with homework, as mediated by parents, provide opportunity and instructions associated with doing homework (Xu \& Carno, 1998), and they can also reinforce the child's good learning behaviour by offering incentives after academic attempts and success. Hoover-Dimpsy and Sandler conclude that major educational outcomes of parents' involvement are in their children's development of skills and knowledge, as well as their personal sense of efficacy to succeed in school.

Durant (2011) writes that parental involvement in children's schooling is an important component of their early school success, echoing findings of Lee and Bowen (2006) from a study of the level and impact of five types of parent involvement in elementary school children's academic achievement by race/ethnicity, poverty, and parent educational attainment. The sample of their investigation comprised 415 third through fifth graders who completed the Elementary School Success Profile. Parents with different demographic characteristics exhibited different types of involvement, and 
those from dominant groups had the strongest association with achievement. However, contrary to theoretical expectations, members of dominant and non-dominant groups benefited similarly from certain types of involvement and differently from others. As Zhang, Hsu, Kwok, Benz and Bowman-Perot (2011) argue, it is difficult to estimate the effect of some specific parental engagements.

Most researchers maintain that parents have an important influence on children's personality and social development (Graig, 1992; Overett \& Donald, 1998; Wintre \& Sugar, 2000). Topping (1986) concurred that parents are role models to their children who transmit, through examples, values, norms, and attitude. The basis for co-operative nursery schools is the acceptance of parents as teaching assistants (Yussen \& Santrock, 1982).

In Africa, Mouly (1982, in Mwamwenda, 1995) wrote that if a pupil does not do or complete assignments and the teacher's attempts to change this behaviour are unsuccessful, he/she should bring the problem to the attention of the principal or the parents. The South African Council for Educators (Act 31 of 2000) recognises parents as partners in education and stipulates that educators must do what is practically possible to keep parents adequately and timeously informed about the wellbeing and progress of their learners. Durant's (2011) analysis of Latino families showed that parental involvement was a significant predictor of children's literacy skills above controls and that stronger communication with parents may be instrumental in increasing both home and school involvement among families, creating a possible avenue through which the parents might develop a collective voice within the school sector. Hsu, Zhang, Kwok, Li, and Ju (2011) used a sample drawn from Taiwan to evaluate the role of parental involvement and found that mothers were more involved than fathers in education and that their involvement had more predictive power of adolescent academic achievement. In another study, Zhang, Hsu, Kwok, Benz, Bowman-Perot (2011) observed that engagement at home was found to have a positive impact on student achievement, but participation in school activities did not significantly affect it.

Nye, Turner and Schwartz 2006) support the use of parental involvement to improve children's academic performance, and argue that its effect outside school has practical implications for parents, educators, administrators, and policymakers. In addition, when used as a supplementary intervention it increases children's academic achievement, with programmes also a way of encouraging involvement.

In their involvement in their children academic success, parents send their children to boarding schools so that they can spend more time in the academic environment, with some assuming the institutions can enhance their children's' academic achievement. Sihlezana (1990) found statistically significant differences between boarding and nonboarding school in terms of academic achievement. There is significant difference in reading and note taking between day and boarding students' study habits Abdullahi, (2010). Abdullahi also observed that the home environment compared very unfavourably with a school environment in which the boarders have their schedule planned by the school authorities and, where available, the schedules are supervised by the school counsellor or personnel on duty. Thus, boarders have the advantage of being supervised and encouraged to form good study habits, these being some of the conditions that may have helped them to excel in the variable of reading and note taking over the day students.

Closely related to boarding and non-boarding schools is out-of-class learning, which Pike (1999) reports has a positive effect, confirmed by Terenzini, Pascarella, and Blimling (1996), who maintained that student-out-of-class experience appears to be far more influential in student academic and intellectual development, and Golde and Pribbenbow, (2000:27), who concluded by asking: "Who benefits when faculty and student interact outside the classroom, in the residential hall?" and answering "Students certainly do."

\subsection{Parental interest}

A child's actual school involvement is directly related to parental interest-developing behaviour, but not significantly related to the parental-controlling behaviour (Georgiou, 1999). When parents' behaviour is that of developing interest of the child in academic activities, the child's involvement in school activities increases, but when the parent's behaviour is that of instructing and controlling the child's academic interest, his/her involvement in school activities deteriorates or does not have any significant impact.

Parents' interest can manifest itself in their attitudes, for instance, the simultaneous influences of families and schools have an important impact on students' learning and achievement (Tatto, Rodrigues, Gonzales-Lantz, Miller, Bussher, Trumble, Cantino \& Woo, 2001). These researchers were supporting Epstein (1987) and Epstein and Daumber (1991, in Tatto et al., 2001), who wrote that teachers' involvement of parents makes those parents feel more effective in helping their children to develop a more positive attitude towards school and their children's school performance. The kind of leadership may also show parents' interest, with Hichman, Bartholomae, and McKenry (2000) writing that 
authoritative parents have a positive impact on their children's academic achievement.

In South Africa, Cherian (1991) researched the relationship between parental interest and academic achievement, using 1021 Xhosa pupils (369 boys and 652 girls) whose ages ranged from 13 to 17 years (Mean age $=15.6$ years) and a random sampling of a Standard 7 population of the Transkei. From interviews used to collect data on parental interest in the education of their children it was discovered that there was a significant relationship between it and academic achievement. Malehase (1997) supported her by maintaining that there was a low, positive, and statistically significant relationship between parental control and academic achievement of children from two-parent families. A negative relationship however existed between parental encouragement and scholastic achievement of children from single-parent families (Malehase, 1997).

\subsection{Parental education}

Parents with a high level of education are capable of providing a learning environment that is specifically structured towards promoting cognitive abilities (Blackmon \& Drum, 1995). In Zambia, Kapambwe (1980) found that academic achievement was significantly related to high parental education. High achievement pupils come from homes with better educated parents and more favourable reading habits. The researcher established that parents of $56 \%$ of the high achievement learners had been to Junior Secondary School, compared to $10 \%$ of the low achievers, neither of whose parents had such qualifications. Kapambwe used a stratified sample of 200 students who wrote Junior Secondary School Leaving Examination (JSSLE) to the average age of 16. Secondary School Leaving Examination results and Student Questionnaires were used as measuring instruments.

In South Africa, Cherian (1996) revealed a significant difference between the attitude of pupils whose fathers and mothers had diverse education. Standard 10 plus diploma or degree holding fathers and mothers' children had the most positive attitude towards Science. Moeketsi (1998), however, found no significant relationship between parental education and scholastic achievement of learners.

\subsection{Parental income and socio-economic status}

Wagmiller, Gershoff, Veliz,and Clements, (2010) found that a marriage by single mothers is associated with modest but statistically significant improvements in the child's academic achievement trajectories, though only in more advantaged cases. Sean (2011) examined whether and how the relationship between family socio-economic characteristics and academic achievement has changed during the last 50 years, and concluded that the income gap between high- and low-income families has widened, as has the achievement gap between children in high- and low-income families. Sean further found that the relationship between parental education and children's achievement has remained relatively stable during the last 50 years, whereas the relationship between income and achievement has grown sharply. Family income was nearly as strong as parental education as a predictor of children's achievement.

From the time children attend school, parents with a high socio-economic status showed a marked interest in their children's academic career, urging greater effort, praising indications of progress, and frequently providing rewards. Such parents did not mind spending money for accomplishment in school (Marjoribanks, 1977). There was a significant relationship between parental occupation and pupils' scholastic achievement (Ogundare, 1991; Moeketsi, 2000; Parkinson, Wallis, Prince, Harvey \& Smith, 1979). From Cherian's (1989) study of the relationship between academic achievements of children of divorced parents, that of children whose parents were divorced or separated was significantly lower than that of the children whose parents were neither divorced nor separated. The researcher, in another study, found that pupils whose fathers and mothers were teachers had a positive attitude towards Science (Cherian, 1996). In another she investigated the relationship between birth order and academic achievement as well, using 242 Standard 7 Xhosa pupils whose parents were divorced or separated and 713 pupils whose parents were neither divorced nor separated (Cherian, 1990). Studying learners in the range of 13-17 years, the results indicated a significant negative relationship between birth order and the children's academic achievement.

Contrary to the above relationships, some researchers did not find any relationship. Moeketsi (2000), for instance, indicated no significant relationship between parental aspiration and involvement and scholastic achievement, or statistical relationship between socio-economic status and academic achievement. Georgiou (1999), however, concluded that parent and child attributions are not strongly or reliably related. 


\section{The Research Focus}

Although the Limpopo Province strives towards offering quality education for all, schools continue to differ in levels of parental involvement, in particular with Grade 12 learners. The research therefore set out to determine whether there was any significant difference in the parental involvement among schools in the Capricorn District of the Limpopo Province, and whether the parental involvement had any relationship with the academic achievement of Grade 12 learners.

The research sought to answer the following research questions:

1. Is there a significant difference in parental involvement and other support systems between boarding and nonboarding schools?

2. Is there a significant difference between low and high achieving schools in parental involvement and other support systems?

The above research questions lead to the following research hypotheses

$H_{0} 1$ There is no difference in parental involvement and other support systems between boarding and non-boarding schools.

$H_{1} 1$ There is a significant difference in parental involvement and other support systems between boarding and nonboarding schools.

$H_{0} 2$ There is no significant difference between low and high achieving schools in parental involvement and other support systems.

$H_{1} 2$ There is a significant difference between low and high achieving schools in parental involvement and other support systems.

\section{Methods}

The sample consisted of 51 schools selected from six areas, which were randomly selected from a population of 339 schools of the Limpopo Province's Department of Education in the Capricorn District. The district was made up of six areas, Bochum, Kone-kwena, Mankweng, Mogodumo, Polokwane and Mankweng districts. The 51 principals were selected from a total of 339 across the district. The schools that participated were those that had written the matriculation examination of the South African Certification Council the previous year. Two schools did not feature in the summary report of the Capricorn District. Only schools in the Capricorn District (Formally Central Region) were eligible to be included in this study. Ten of these schools had boarding houses whereas the remaining 41 had none. All areas had at least one or more boarding schools, except the Zebediela Area, which had none (See Table 1).

Table 1. Sample of schools from the Capricorn district

\begin{tabular}{|l|c|c|c|c|c|}
\hline \multirow{2}{*}{ Name Of Area } & \multirow{2}{*}{ No. of Schools } & \multicolumn{3}{|c|}{ Schools Participated } & $\%$ Participation \\
\cline { 3 - 6 } & & Non-boarding & Boarding & Total & \\
\hline 1. Bochum & 74 & 6 & 1 & 7 & $8 \%$ \\
\hline 2. Konekwena & 58 & 8 & 1 & 9 & $15 \%$ \\
\hline 3. Mankweng & 59 & 7 & 3 & 10 & $12 \%$ \\
\hline 4. Mogodumo & 53 & 6 & 3 & 9 & $17 \%$ \\
\hline 5. Polokwane & 60 & 6 & 2 & 8 & $13 \%$ \\
\hline 6. Zebediela & 34 & 8 & 0 & 8 & $23 \%$ \\
\hline TOTAL & 339 & 41 & 10 & 51 & $15 \%$ \\
\hline
\end{tabular}

\subsection{School Environmental Questionnaire}

The questionnaire used to collect data was the School Environmental Questionnaire (SEQ), Section 1 of which established whether or not the school was boarding. The respondents to this section were the principals, and no points were allocated to this section (See Table 2, below). The questionnaire also collected information regarding parental involvement. The principals and teachers completed this section, which was aimed at collecting data about parents' involvement in their children's academic activities.

Table 2. Section 1 of the School Environmental Questionnaire (Type of school) 


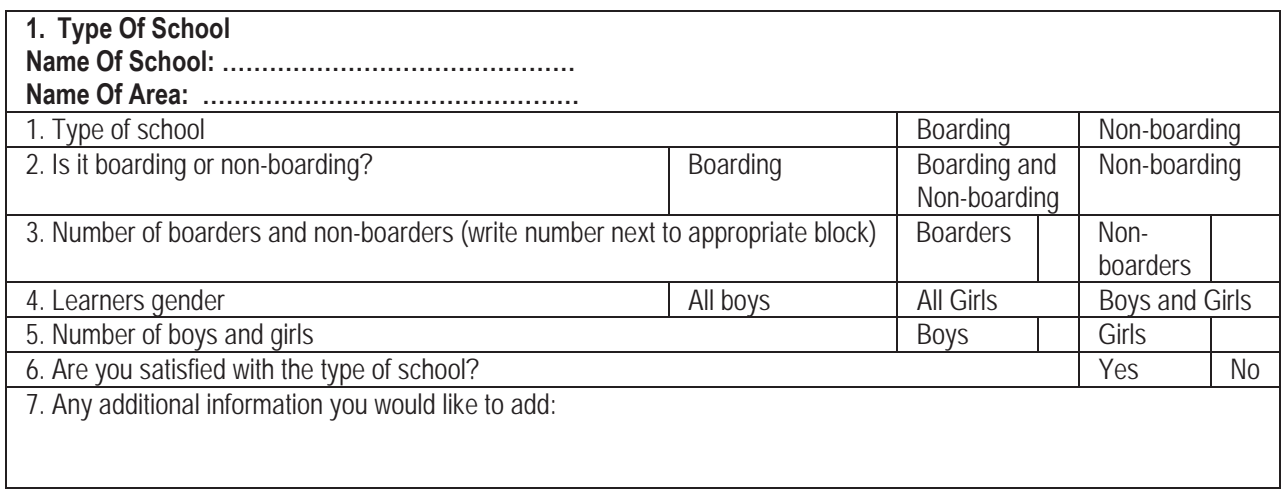

Table 3 (below) explains the items of section 5. The "yes" response was allocated a point while the "no" allocated a zero. A high score indicated good parental involvement and efficient use of other support systems by the principals and teachers.

Table 3. Section 5(a) of the School Environmental Questionnaire. (Parental involvement and other support by principals and teachers)

\begin{tabular}{|l|l|l|}
\hline 5. Parents' Involvement and other Support & Yes & No \\
\hline 1. Do parents get involved in their children's academic activities? & Yes & No \\
\hline 2. Is parents' attendance of meetings good? & Yes & No \\
\hline 3. Does your school have sponsor(s)? & Yes & No \\
\hline 4. Do you utilise the service of a Psychologist? & Yes & No \\
\hline 5. Do Psychologists discuss the results with the learner/ teacher/ parents? & Yes & No \\
\hline 6. How often do you hold meetings with parents? Monthly Q Quarterly & Per semester & Annually \\
\hline 7. Are you satisfied with parental involvement in the school? & Yes & No \\
\hline 8. Any additional information you would like to add: & \\
& \\
& \\
\end{tabular}

The questionnaires were forwarded to academics in the field of Research and Educational Psychology in the Faculty of Humanities of the University of the North for evaluation, who confirmed that the contents of the questionnaire seemed to be relevant. Educators and research officials confirmed that the School Environmental Questionnaire could measure the environment of the school and particularly the qualifications of teachers in schools.

\section{Summary of Results}

The Capricorn District had a summary of the Grade 12 results for all its areas, each submitted to the district office by the areas themselves, then in turn to the provincial head office. The document was in column form (See Annexure 1), from which the researchers worked out the percentage passed with exemption per school. The percentage passed with exemption represents the academic achievement of each school. If a school had obtained a high percentage pass with exemption, it means that it had obtained high academic achievement. If it had obtained a low percentage pass with exemption it means it had obtained a low academic achievement.

A pilot study provided an opportunity to assess the appropriateness and practicality of the data collection instrument, the questionnaire (Cherian, 1996) and develop interest from respondents (Haralambos \& Holbom, 2000). The pilot study was carried out before the schools closed for the winter vacations. Schools that took part in the pilot study were Reholegile High from the Zebediela area, Mapelwana High from the Mankweng area, and Manyong High in the Polokwane area. The principal, one teacher, and three learners completed the questionnaires (See Table 4, below). The outcome of the pilot study was that after each section, the questionnaire asked "others?" The participants gave answers that did not constitute the intention of the question. It showed that the participants did not understand it, and the question was then changed to "Any additional information you would like to add?" 
Table 4. Sample of pilot study

\begin{tabular}{|c|c|c|c|c|c|c|c|}
\hline \multicolumn{3}{|c|}{ School Profile } & \multicolumn{3}{c|}{ Participation } \\
\hline Name of school & $\begin{array}{c}\text { No. of } \\
\text { Learner }\end{array}$ & $\begin{array}{c}\text { No. of } \\
\text { Teacher }\end{array}$ & No. of Principals & $\begin{array}{c}\text { No. of } \\
\text { Learners }\end{array}$ & No. of Teachers & $\begin{array}{c}\text { No. of } \\
\text { Principals }\end{array}$ & $\begin{array}{c}\text { Total } \\
\text { Filled }\end{array}$ \\
\hline 1. Reholegile & 927 & 36 & 1 & 7 & 4 & 1 & 12 \\
\hline 2. Mapelwana & 514 & 12 & 1 & 8 & 2 & 1 & 11 \\
\hline 3. Manyong & 350 & 8 & 1 & 3 & 1 & 1 & 5 \\
\hline
\end{tabular}

This research study used a t-test to determine if there was a significant difference in the parental involvement and other support systems between boarding and non-boarding schools. It also determined if there was a significant relationship between parental involvement and other support systems and academic achievement. Lastly, it investigated if there was any significant difference in academic achievement between boarding and non-boarding schools. The t-test compared the mean of parental involvement and other support systems between boarding and non-boarding schools (See Table 5, below). It indicates that the $\mathrm{p}$-value is less than the 0.01 significance level. The null hypothesis is rejected and the research hypothesis accepted. It can therefore be concluded that there is a highly significant difference in the parental involvement and other support systems between boarding and non-boarding schools.

Table 5. Parental involvement between boarding and non-boarding schools

\begin{tabular}{|l|c|c|c|c|}
\cline { 2 - 4 } \multicolumn{1}{c|}{} & N & Mean & SD & P-Value \\
\hline Boarding & 10 & 5.50 & 1.494 & \multirow{2}{*}{$0.005 \#$} \\
\hline Non-Boarding & 41 & 3.80 & 1.847 & \\
\hline
\end{tabular}

Parents whose children were in boarding schools participated more than those whose children were in non-boarding schools (See Table 6, below), as evidenced by all parents whose children were in boarding schools saying they participated in their children's academic activities, compared to those of children in non-boarding schools, $40 \%$ of parents did not participate. Most of the non-boarding schools in this study are in rural areas characterised by parents who are semi-illiterate. Utilization of a school psychologist or a school counsellor in boarding schools is nearly triple that of nonboarding schools, because the former have more resources, including money to pay for their services. The same applies to parents' meeting with the school. Those whose children attend boarding schools are mostly educated and have money, and as such they understand the importance of meetings for their children's academic achievement. There is a definite correlation between parents' education, parental interest, and parental income or socio-economic status. Interestingly, it seems that none of the boarding schools have sponsor(s), while $7 \%$ of the non-boarding schools claim to have sponsor(s).

Table 6. Percentage response on parental involvement and other support systems between boarding and non-boarding schools

\begin{tabular}{|l|c|c|c|}
\hline \multirow{2}{*}{ Item } & \multirow{2}{*}{ Response } & \multicolumn{2}{|c|}{ Type } \\
\cline { 3 - 4 } & & Non Boarding & Boarding \\
\cline { 3 - 4 } & & $\%$ & $\%$ \\
\hline PI1. Do parents get involved in their children's & No & 40 & - \\
\cline { 2 - 4 } academic activities? & Yes & 60 & 100 \\
\hline \multirow{2}{*}{ PI2. Is parents' attendance of meetings good? } & No & 75 & 30 \\
\cline { 2 - 4 } & Yes & 25 & 70 \\
\hline \multirow{2}{*}{ PI3. Does your school have sponsor(s)? } & No & 92.2 & 100 \\
\cline { 2 - 4 } & Yes & 7.3 & - \\
\hline \multirow{2}{*}{ PI4. Do you utilise the service of a Psychologist? } & No & 73.2 & 40 \\
\cline { 2 - 4 } & Yes & 26.8 & 60 \\
\hline PI5. Do Psychologists discuss the results with the & No & 75 & 40 \\
\cline { 2 - 4 } learner/teacher/parents? & Yes & 25 & 60 \\
\hline \multirow{3}{*}{ PI6. How often do you hold meetings with parents? } & Monthly & - & 10 \\
\cline { 2 - 4 } & Quarterly & 60 & 40 \\
\cline { 2 - 4 } & Semester & 22.5 & 30 \\
\cline { 2 - 4 } & Annually & 17.5 & 20 \\
\hline
\end{tabular}


P17. Are you satisfied with the parental involvement in the school?

\begin{tabular}{|c|c|c|}
\hline No & 77.5 & 40 \\
\hline Yes & 22.5 & 60 \\
\hline
\end{tabular}

To compare the mean percentage of parental involvement and other support systems with academic achievement of Grade 12 learners, the t-test was used (See Table 7, below). It indicates that the p-value is greater than the 0.05 significance level. The null hypothesis is accepted and the research hypothesis rejected. It can thus be stated that there is no significant difference between low and high achieving schools in parental involvement and other support systems.

Table 7. Relationship between parental involvement and other support systems and academic achievement

\begin{tabular}{|l|c|c|c|c|}
\cline { 2 - 4 } \multicolumn{1}{c|}{} & $\mathrm{N}$ & Mean & SD & P-Value \\
\hline Low Academic Achievement & 30 & 3.93 & 1.461 & \multirow{2}{*}{0.201} \\
\hline High Academic Achievement & 19 & 4.47 & 1.389 & \\
\hline
\end{tabular}

The higher mean academic achievement indicates that high performing schools enjoy more parental involvement and other support systems, although this is not statistically significant. All the high performing schools do not have sponsors, while $10 \%$ of the low performing schools do have sponsors (See Table 8, below). The outcomes of this research differ from those of Hoover-Dimpsy and Sandler (1995), who found that parental involvement influences children's development and educational outcomes. Xu and Lyn (1998) on the other hand, maintain that everyday experiences associated with doing homework as mediated by the parents, provide sufficient opportunity and instruction for doing their homework. Other researchers who differ with the finding include Georgiou (1999); Overett and Donald (1998); Hichman, Batholoae, and McKenry (2000); Cherian (1996); and Malehase (1997). However, they nearly concur with the finding of Moeketsi (1998), who established no significant relationship between parental education and scholastic achievement. The low achievement schools do not have monthly meetings with the parents, while $5 \%$ of the high performing schools prefer to have meetings with the parents of the learners.

Table 8. Percentage response on parental involvement and other support systems between low and high academic achievement

\begin{tabular}{|l|c|c|c|}
\hline \multirow{2}{*}{ Item } & \multirow{2}{*}{ Hesponse } & \multicolumn{2}{|c|}{ Academic Achievement } \\
\cline { 2 - 4 } & & Low A.A & High A. \\
\cline { 2 - 4 } & & $\%$ & $\%$ \\
\hline \multirow{2}{*}{ PI1. Do parents get involved in their children's academic activities? } & No & 44.8 & 15.8 \\
\cline { 2 - 4 } & Yes & 55.2 & 84.2 \\
\hline \multirow{2}{*}{ PI2. Is parents' attendance of the meetings good? } & No & 75.9 & 52.6 \\
\cline { 2 - 4 } & Yes & 24.1 & 47.4 \\
\hline \multirow{2}{*}{ PI3. Does your school have sponsors(s)? } & No & 90 & 100 \\
\cline { 2 - 4 } & Yes & 10 & - \\
\hline \multirow{2}{*}{ PI4. Do you utilise the service of the Psychologist? } & No & 66.7 & 63.2 \\
\hline \multirow{2}{*}{ PI5. Does Psychologist discuss the results with the learners/ teachers/ parents? } & Yes & 33.3 & 36.8 \\
\cline { 2 - 4 } & No & 69 & 63.2 \\
\hline \multirow{2}{*}{ PI6. How often do you hold meetings with parents? } & Monthly & 31 & 36.8 \\
\cline { 2 - 4 } & Quarterly & 51.7 & 5.3 \\
\cline { 2 - 4 } & Semester & 20.7 & 37.9 \\
\cline { 2 - 4 } & Annually & 27.6 & 5.3 \\
\hline \multirow{2}{*}{ PI7. Are you satisfied with the parental involvement of the school? } & No & 79.3 & 57.9 \\
\cline { 2 - 4 } & Yes & 20.7 & 42.1 \\
\hline
\end{tabular}

To compare the mean percentage of academic achievement between boarding and non-boarding schools, the t-test was used (See Table 9). It indicates that the p-value is 0.010 at 0.05 level of significance. Because p-value is less than 0.05 , the null hypothesis is rejected and the research hypothesis accepted. There is a significant difference in academic achievement between boarding and non-boarding schools. 
Table 9. Academic achievement of Grade 12 learners between boarding and non-boarding schools

\begin{tabular}{|l|c|c|c|c|}
\cline { 2 - 4 } \multicolumn{1}{c|}{} & $\mathrm{N}$ & Mean & SD & P-Value \\
\hline Boarding & 10 & 51.0660 & 31.93321 & \multirow{2}{*}{$0.010 \#$} \\
\hline Non-Boarding & 39 & 18.4880 & 14.33441 & \\
\hline
\end{tabular}

\# significant

Boarding schools scored higher in academic achievement. This concurs with the finding by Sihlezana (1990) who established that boarders outperform non-boarders in academic achievement. In boarding schools, pupils spend more time in the school campus. They have more time to do their schoolwork and this may be a contributory factor to their good performance. Pupils who are non-boarders do extra work when they are at home. For example, girls fetch water, prepare food for the family, and do such work as washing dishes and clothes at the expense of their schoolwork. This contributes to their poor school work. United Nations Children Education Fund (UNICEF) (2004) maintains that this situation contributes to absenteeism and the high dropout rate of girls.

\section{Conclusion}

The results show a significant difference in the parental involvement and other support system between boarding and non-boarding schools. Factors that contribute to parents' participation are parental interest, parental education and parents' socio-economic status. Other support systems include the utilisation of school psychologists and psychological results. Parents' involvement in their children's academic activities is influenced by their interest, socio-economic status, and level of education. Most parents who send their children to boarding schools are those who have a high level of education with a good financial background to afford the fees of such schools.

The researcher recommends parental involvement in all schools (both boarding and non-boarding) as the literature review indicated that it positively correlates with the academic achievement of learners. Stakeholders, including parents, can utilize other formations and structures (such as the SGB) created by the government that aim at including parents in the governing of schools. Community schools have other committees that look after the well-being of the school. Parents can work closely with these committees in order to identify and satisfy the needs of their children.

In terms of boarding and non-boarding schools, this does not necessarily mean that everyone sends their children to boarding schools. A mixture and of parent involvement and sending children to boarding schools can definitely improve children's academic progress. On the other hand, maybe government may give grants to poor families to send their children to boarding school.

\section{References}

Abdullahi, O.E. (2010). Comparative Study of Kwara State Secondary School Students' Study Habits in English Language: Implication for Counselling. The Social Sciences, 5(6), 514-519

Blackmon, T.C. \& Drum, M.W. (1995). Children's Self-Esteem and their Parents' Education. Psychological Reports, 80, 1-114.

Cherian, L. (1996). The attitude of Standard 10 pupils towards Science in Earstwhile Lebowa. Unpublished Doctoral Thesis, University of the North, SA.

Cherian, V.I. (1989). Academic Achievement of children of divorced parent Psychological Report, 64, 355-358.

Cherian, V.I. (1990). Relationship between corporal punishment and academic achievement. South African Journal of Education, 10 (1), 96-100.

Cherian, V.I. (1991). Parental Interest and Academic Achievement of Xhosa Children. Psychological Reports, 69, 183-188.

David R. T. Susan P. K., Terri L. S. \& Susan D. C. (2010). Parent involvement and student academic performance: A multiple mediational analysis. Journal of Prevention Intervention Community, 38(3): 183-197.

Durant, T.M. (2011). Latino Parental Involvement in Kindergarten Findings From the Early Childhood Longitudinal Study. Hispanic Journal of Behavioral Sciences, 33(4), 469-489.

Georgiou, S.N. (1999). Achievement Attribution of Sixth Grade Children and their Parents. International Journal of Experimental Educational Psychology, 19, 399-412.

Golde, C.M. \& Pribbenbow, D.A. (2000). Understanding Faculty Involvement in Residential Learning Communities. Journal of College Student Development, 41, 27-40.

Graig, G.J. (1992). Human Development. New Jersey: Prentice Hall.

Haralambos, M. \& Holborn, M. (2000). Sociology. Themes and perspectives. London: Harper Collins Publishers.

Hichman, G.P., Bartholomae, S. \& McKenry, P.C. (2000). Influence of Parenting Style on the Adjustment and Academic Achievement of Traditional College Freshmen. Journal of College Student Development, 41, 41-51. 
Hoover-Dimpsy, K.V. \& Sandler, H.M. (1995).The influence of parental involvement in children development and education outcomes. Teachers College Record, 97, 310-331.

Hsu, H., Zhang, D., Kwok, O., Li, Y., and Ju, S. (2011). Distinguishing the Influences of Father's and Mother's Involvement on Adolescent Academic Achievement Analyses of Taiwan Education Panel Survey Data. The Journal of Early Adolescence, 31(5), 694-713

Huysamen, G.K. (1995). Psychological Measurement: An introduction with South African Examples. Pretoria: Academic.

Kapambwe, G.M. (1980). An investigation into the relationship between Home Background and Scholastic Achievement of a group of Junior Secondary School Pupils in Zambia. Unpublished Master's Dissertation, University of Zambia, Zambia.

Lee, J. \& Bowen, N. (2006). Parent Involvement, Cultural Capital, and the AchievementGap Among Elementary School Children. American Education Research Journal, 43(2), 193-218.

Malehase, M.C. (1997). The relationship between family background factors and scholastic achievement of children from single and twoparent families in the Mankweng Education Circuit of South Africa. Unpublished Masters Dissertation, University of the North, SA.

Marjoribanks, K. (1983). Ethnic Families and Children's Achievement. London: Allyn and Unwin.

Msibi, N. (2012). Thobela FM, South African Broadcasting Corporation (SABC) Tabakgolo Programme, March, $12,2012$.

Moeketsi, J.A. (2000). Non-Intellective Psychosocial factors emerging from the Home and the Scholastic Achievement of high school pupils in the Northern Province of South Africa. Unpublished Master's Dissertation, University of the North, SA.

Motloutsi, D.E.T. (1982). Library Programmes as an intergral part of non-formal education with special reference to Lebowa. Unpublished Masters Dessertation, University of Orange Free State, SA.

Mwamwenda, T.S. (1995). Educational Psychology: An African perspective. Durban: Butterworth.

Nye, C., Turner, H. M., \& Schwartz, J. B. (2012). Approaches to Parental Involvementfor Improving the Academic Performance of Elementary School Age Children.From:http://www.sfi.dk/graphics/Campbell/reviews/parental_involvement_review pdf. January 2012

Ogundare, S.F. (1991). Correlate of Citizenship Behaviour in Nigeria Secondary Students. Educational Studies, 17(2), 149-156.

Overett, J. \& Donald, D. (1998). Paired rearing: Effect of parent involvement programme in Disadvantaged Communities in South Africa. British Journal of Educational Psychology, 68, 347-356.

Parkinson, C.E., Wallis S.M., Prince J., Harvey D. \& Smith, B. (1982). Rating the Home Environment of School-Age Children. A comparison with general Cognitive Index and School progress. Journal of Child Psychology, Psychiatry and Allied Disciplines, 23(3), 329-333.

Pearson, L. (1994). Experimental Methodology. London: Allyn and Bacon,

Pike, G.R. (1999). The Effect of Residential Learning Communities and Traditional Residential Living Arrangements on Educational Gains during the first year of college. Journal of College Student Development, 40, 269-284.

Wagmiller, R.L., Gershoff, E., Veliz P. and Clements, M. (2010). Does Children's Academic Achievement Improve when Single Mothers Marry? Sociology of Education, 83(3) 201-226.

Sean F. Reardon, (2011). The Widening Academic Achievement Gap between the Rich and the Poor: New Evidence and Possible Explanations. New York: Russell Sage Foundation.

Sihlezana, N.P. (1990). An investigation into the academic achievement of resident and non-resident Std 10 students at Umzimkhulu district of Transkei. Unpublished Master's Dissertation. University of Transkei.

South African Council for Educators Act 31 of 2000. Pretoria: S.A. Government Printers,

Tatto, M.T., Rodridgez, A., Gonzalez-Lantz, L.D., Miller C., Bussher, M., Trumble, D.,Canteno, R., \& Woo, A. (2001).The influence of a family and school on student learning and achievement. Review of Education, 7, 315 -333.

Terenzini, P.T., Pascarella, E.T., \& Blimling, G.S. (1996). Students' Out-of-Class Experiences and their influence on Learning and Cognitive Development: A literature review. Journal of College Student Development, 37(2), 149-162.

Trumble D.,Canteno, R., \& Woo, A. (2001).The influence of a family and school on student learning and achievement. Review of Education, 7, $315-333$.

Topping, K.J. (1986). Parents as educators. London: Croom Helm.

United Nations Children Education Fund. (2004). Water, environment, and sanitation Water, sanitation, and education. July 01, 2004, from http:// www.unicef.org.dfgdfgdfgdfgd

Wintre, M.G. \& Sugar, L.A. (2000). Relationship with Parents, Personality and University Transition. Journal of College Student Development, 41, 202-214.

Xu, J. \& Carno, L.. (1998). Case study of Families doing 3rd Grade Homework. Teachers College Record, 100, $204-436$.

Yussen, S.R. \& Santrock, J.W. (1982). Child Development: An introduction. Dubanque, lowa: Wm. C. Brown Company Publishers.

Zhang, D., Hsu, H., Kwok, O., Benz, M. Bowman-Perot, L. (2011). The Impact of Basic Level Parent Engagements on Student Achievement: Patterns Associated with Race/Ethnicity and Socioeconomic Status (SES). Journal of Disability Policy Studies, 22 (1), 28-39. 
